\title{
The importance of environmental aspects of packaging
}

\author{
Jacqueline L. Spence* \& David A. Ogg \\ Graduate School of Business Administration, University of the Witwatersrand, P.O. Box 98, Wits 2050, Republic of South Africa
}

Received February 1994, accepled May 1994

\begin{abstract}
Increasing attention is being paid to packaging, a component of product in the marketing mix. It is being recognized that packaging is important not only from a functional viewpoint, but also in terms of marketing to the customer. One of the constraints on packaging is environmental issues. These are becoming increasingly important internationally, from both a legislative and consumer perspective. In this study the perceptions of the members of the packaging value chain as regards the functional, marketing and environmental issues surrounding packaging are examined. It is found that functional aspects appear to be the most important, followed by marketing aspects. Environmental concerns are rated as unimportant. This is despite evidence that these issues should be regarded with increasing importance based on international trends. However, the relative importance of environmental packaging issues is greatest amongst rawmaterial suppliers, followed by packaging and fast moving consumer goods (FMCG) suppliers. Retailers have the least interest.
\end{abstract}

Toenemende aandag word gegee aan verpakking, 'n komponent van die produk in die bemarkingsamestelling. Daar word erken dat verpakking nie net uit 'n funksionele oogpunt belangrik is nie, maar ook wat bemarking aan die klant betref. Een van die beperkings op verpakking is omgewingsake, wat uit 'n wetgewende sowel as klanteperspektief al hoe belangriker op intemasionale gebied word. In hierdie studie word ondersock ingestel na die persepsies van die lede van die verpakkingswaardeketting ten opsigte van die funksionele, bemarkings- en omgewingaangeleenthede rakende verpakking. Daar is gevind dat funksionele aspekte die belangrikste blyk te wees, gevolg deur bemarkingsaspekte. Kommer oor dic omgewing word as onbelangrik beskou, ondanks bewyse dat hierdie angeleentheid, indien na internasionale tendense gekyk word, as toenemend belangrik beskou moet word. Die relatiewe belangrikheid van omgewingsverpakkingsaangelcenthede word egter die hoogste aangeslaan deur die verskaffers van grondstowwe, gevolg deur die verskaffers van verpakkingsmateriaal en vinnig bewegende verbruikersgoedere. Kleinhandelaars het die minste belang by omgewingsverpakkingsaangeleenthede.

*Author to whom correspondence should be addressed.

\section{Introduction}

Packaging, a component of product in the marketing mix, has been described as 'one of the most neglected areas of marketing' (Runyon, 1982).

Many authors, however, state categorically that the extemal packaging is one of the most important elements in the marketing mix as it is essentially the only piece of product information that every consumer sees.

'Today ... the marketing significance of packaging is fully recognised and packaging is truly a major competitive force in the struggle for markets ... new developments in packaging, occurring rapidly and in a seemingly endless flow, require management's constant attention to packaging design' (Stanton, Etzel, Walker, Abratt, Pitt \& Staude, 1989: 246).

The theory of packaging in marketing has evolved from a focus on the functionality of packaging to an increasing awareness of the constraints on the packaging decision. One of these constraints is the environmental impact of packaging.

Freeman (1989) states that a majority of consumers claim that environmental concerns affect their choice of produch, even if they must pay a higher price. Rice (1990) comments that a Michael Peters Group poll reported that three-quarters of consumers are willing to pay more for recyclable or biodegradable packaging. McDaniel \& Rylander state that this increased environmental consciousness means that consumer marketers should

'recognise a product's environmental implications; analyze the changing consumer and political attitudes while recognizing the role that companies can play in protecting the environment; realize that green marketing is not purely altruistic - it can be a profitable endeavour; and recognize that green marketing must be a fully integrated part of a firm's strategic marketing plan' (1993: 5).

Packaging represents $30 \%$ by weight of municipal waste after recovery of recycled materials in the U.S. (Caimcross, 1990). Similar percentages are found in Australia - between $28 \%$ and $34 \%$ (Puplick, 1992). A C.S.I.R. survey conducted in 1991, estimated the quantity of packaging/container waste discarded annually in South Africa as $1.3 \mathrm{mil}$ lion tons. Litter amounts to approximately 200000 tons. In terms of export, there are implications for South African converters and packagers. Intended E.U. and U.S. legislation and codes of practice will provide barriers to entry for export into those countries. The legislative and social pressures which the American and European packaging value chains are encountering has potential consequences for South African packagers, FMCG suppliers and retailers.

Thus, how the value chain responds to environmental packaging issues and how packaging companics intend to address potential threats, are important for their strategies, image and long term survival.

The packaging dilemma consists of how to satisfy the functional and marketing requirements as well as the social and environmental demands, now and in the future.

In this study the perceptions of the members of the packaging value chain are examined as regards the functional, marketing and environmental issues surrounding packaging. 


\section{Literature review}

Packaging is defined by Kotler (1991: 449) as 'all the activities of designing and producing the container or wrapper for a product'. Thus the packaging encompasses a broad area, and has many conflicting demands, constraints and trade-offs (Danton de Rouffignac, 1990; Marcus, 1975; Phelps \& Westing, 1968).

Essentially three elements of packaging emerge from the literature - functional issues, marketing issues and constraints. Constraints identified include economic aspects, legislation and environmental issues (Marcus, 1975; Phelps \& Westing, 1968).

The degree of importance of each element differs within the packaging value chain. Davidson (1986) found that marketers, retailers and consumers have different requirements in terms of marketing and functional issues.

Danton de Rouffignac (1990) argues that packaging is now consumer driven. Previously, in common with most of manufacturing, attitudes to packaging were product led.

Consumer attitudes to packaging have not been well researched in South Africa. However, U.S. and U.K. surveys have been published. The survey results by Ashton (1991) indicate that, in addition to functional and marketing requirements, American consumers also require recyclable packaging and infrastructure in place that will make recycling convenient.

Trends which are evident from both U.S. Packaging and U.K. Packaging Week surveys in April 1992 and February 1992 respectively, are as follows:

- Cosmetics are perceived to be the biggest culprit for over-packaging, followed by food, pharmaceuticals and beverages.

- Glass is seen as the most readily recyclable material.

- There is growing interest in concentrated cleaners and powders which require less packaging (Erikson, 1992: 43).

- Environmental information on product labels is considered misleading, confusing and dishonest (Hunt, 1992: 13).

One significant problem with the consumer surveys is the information gap of consumers. The S.A. Co-ordinating Consumer Council refers to

'little understanding of the true connection between specific environmental problems and the consumer behaviour which can ameliorate those problems' (Wilken, 1992).

Ashton (1991: 32-36) found that environmental terms such as recyclable, biodegradable, source reduction, green labelling and environmentally friendly are not understood by many consumers.

Gunn (1972) perceives there to be a conflict of interest between the marketing and sales objectives of packaging and environmental solid waste problems. Business attitudes are geared to the protection of investments in machinery, distribution, marketing styles and corporate image rather than the environment. He identified the problem of no agreement between legislators, business people and technologists on how to dispose of solid waste. In addition, there is public resistance to innovative proposals to handling solid waste. There is concern for the disposability of packages, but little action such as research expenditure on disposability improvement or application was being undertaken.

Both Selke (1990) and Freeman (1980) have made suggestions on ways to improve the environmental impact of packaging. Selke (1990) suggests:

- eliminate heavy metals, e.g. lead based pigments

- design for reusability;

- use single material type where possible;

- use materials which are easily separated or compatible; and

- use recycled materials.

Freeman (1980) suggests:

- reduction in weight of material;

- design for waste reduction in landfill;

- provide containers + infrastructure for consumer recycling;

- design for recyclability; and

- reduction in energy required to manufacture/recycle packages.

Many forms of legislation have been attempted worldwide to decrease the amount of packaging waste from littering or in the municipal waste stream. The variety of regulations include bottle deposit legislation and packaging tax, as well as bans and restrictions on certain types of packaging. Packaging laws differ between countries due to the discrepancies in perceptions as to the seriousness of an environmental problem and what is politically or economically acceptable.

Perchard (1992) reviews the differences in the European environment which results in the variety of pressures on packaging waste. He comments that the Netherlands with a high water table and vulnerability to contamination from landfill sites, has a need for alternative disposal methods, unlike the United Kingdom which uses landfill extensively. Germany is politically anxious to minimize the role of incineration in the powerful, wealthy parts of the country. However, the Danes and Italians are keen on energy from waste incineration as the cleaner, safer and cheaper solution to domestic waste disposal (Perchard, 1992). The most ambitious (or draconian, depending on one's viewpoint) project has been the German Draft Ordinance whereby Germany plans that

'packaging ranging from plastic meat wrappings to $\mathbf{3 0}$ litre paint buckets will be returnable to the point of purchase for disposal' (Time, 20/4/92).

Cairncross (1990) refers to Denmark's highly protectionist measures to ban non-returnable beverage containers.

Dick (1978) concentrates on the non-retumable beverage problem in South Africa and made recommendations based on cost-benefit analysis of deposits, taxes and legislation.

Recommendations of the President's Council Report on the Environment (1991) include a proposed Environmental Management System covering legislation for waste management via a 'Solid Waste Control Act'. The report considers the current South African position as most unsatisfactory and suggests the following waste minimization solutions:

- Deposits on containers and refunds on waste.

- Incentives and rewards for collection of recyclable material.

- More biodegradable materials. 
- Minimizing packaging materials and components.

- More public waste containers and heavier fines for littering.

- Principle of cradle to grave waste management must be applied.

- The Directorate of Environmental Education to coordinate change in public autitudes, and RSC to standardize the requirements and monitoring of solid waste dumps.

- Support the SABS investigation into "eco-labelling" on products'.

It can be seen that the worldwide trend is toward a greater emphasis on environmental issues, both from a consumer and legislative perspective. Consumers are having a greater influence on packaging decisions, and they are indicating a greater awareness of environmental issues. It is high time that the South African packaging value chain began to address these issues.

\section{Methodology}

In this study the perceptions of the members of the packaging value chain, excluding consumers, as regards the functional and environmental issues of packaging are examined. The value chain is shown in Figure 1.

The companies selected for the study were restricted to those involved in the beverage, food, pharmaceuticals and cosmetics industries. All of the materials used in packaging, which includes glass, aluminium, steel, paper/board and plastics, were considered.

A questionnaire was uscd as the measuring tool. The questionnaire contained the following sections:

- Demographic details.

- Sources of information on environmental packaging issues.

- The Packaging Decision: respondents were asked to rccord their views on the importance to their company's packaging decision of 36 statements on a five-point scale, where $1=$ unimportant and $5=$ extremely important. The

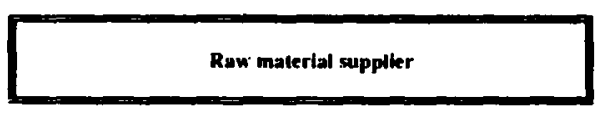

Substrate manufaciurers

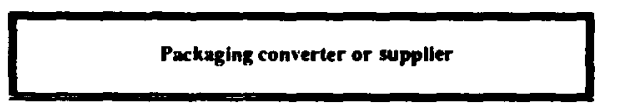

Processing of packagc

$\downarrow$

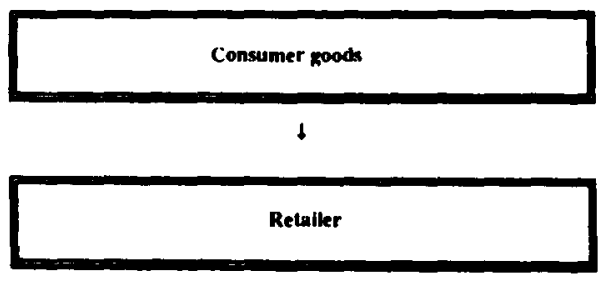

$\downarrow$

Consumer

Domestic usc of package packaging statements were compiled by reviewing marketing literature on packaging and specific literature on environmental packaging issues, and covered functional, marketing and environmental aspects. A list of the statements appears in Table 1.

- Packaging Design and Environmental Issues: respondents were questioned on their perception of their company's involvement in environmental packaging issues using a number of closed questions:

(a) 'What is your perception of your organization's involvement in packaging environmental issues?' This variable, as Rogers (1983) described of the Carter \& Williams (1959) questionnaire, 'is a crude rating of the firm's innovativeness in addressing environmental issues in packaging'. Response options were leadership position, actively involved, starting to take action, not yet involved and no intention of being involved.

(b) The next question probed why there is the current interest regarding environmental issues in packaging. Respondents were given the option of agreeing with three

Table 1 Packaging decision statements

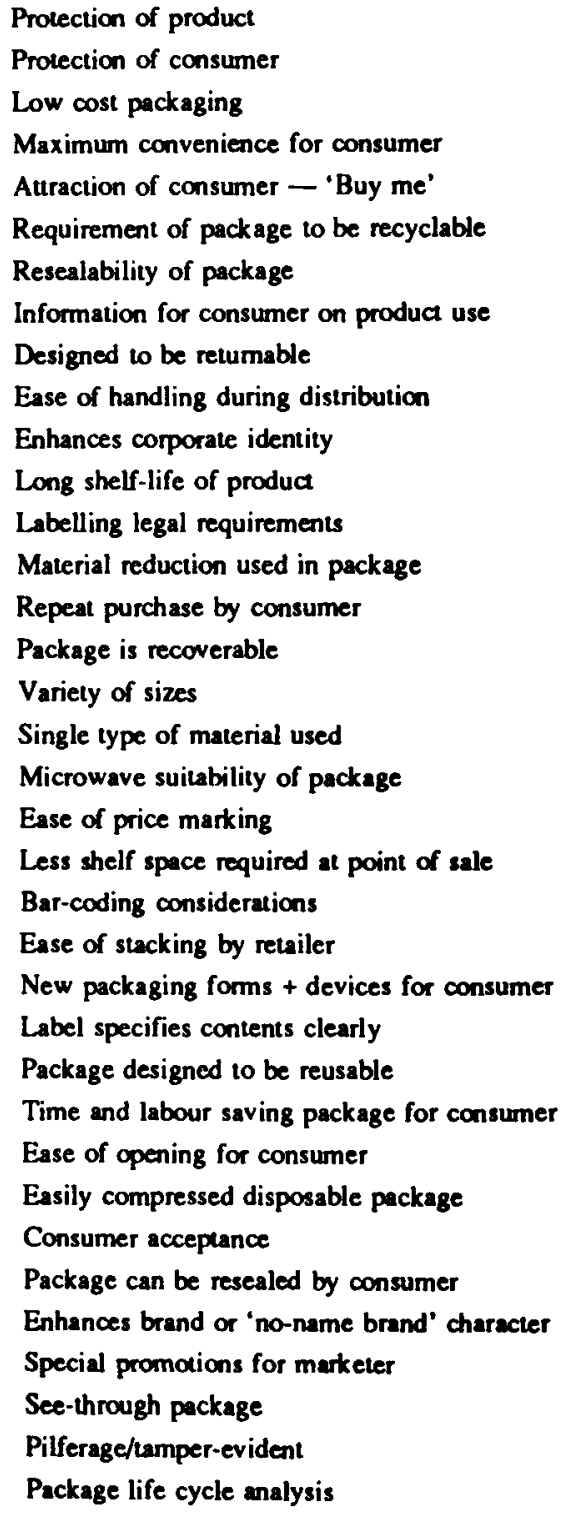


statements: 'a change in consumer's values', 'a mere fad' or 'don't know'. In addition, respondents were invited to offer their own opinions as to why there is such interest.

(c) The five questions asked by Gunn (1972) of the 1000 American readers of Packaging Engineering to probe the company's involvement in environmental packaging issues from a marketing perspective were included. These are: Is your company concerned about the disposability of the packages it uses or produces?; Has your company spent money for research on package disposability?; Has your company made a change in packaging to improve disposability?; Has your company stressed the recyclability of your package as a marketing benefit?; and Have you or your company stressed the use of recycled material in your packages as a marketing benefit?

(d) This was followed by a 5-point scale rating of the degree of company involvement with the 12 suggestions from Selke (1990) and Freeman (1980) on how to reduce the impact of packaging in the waste stream.

In order to prevent any misunderstandings with the wording and questionnaire format, two potential respondents from each of the packaging industry and FMCG industries were used for pre-testing. In addition, the list of packaging attributes was discussed with the Packaging Council of South Africa (PACSA) for a further opinion as to their completeness.

The structured questionnaire was posted to 326 individuals in packaging value chain companies who were in a position to influence the packaging policy of their company, or employed to address environmental and legislative issues. In the majority of companies sampled, the questionnaire was directed to the marketing manager. Respondents were given the option of contacting the author by telephone or fax for assistance.

The sample included privately owned and publicly quoted companies reflecting different positions in the value chain. The sample of raw material suppliers, packaging converters and FMCG suppliers was obtained using all the companies listed in the 1992/3 Buyer's Guide - The Directory for Manufacturers of Food, Beverages, Pharmaceuticals, Cosmetics, Toiletries and Packaging.

The sample of packaging and FMCG suppliers was further supplemented by a systematic sample (every fifth entry) from the Yellow Pages under the headings Packaging Suppliers, Food, Cosmetics, Pharmaceutical, Beverage and Frozen Food Manufacturers and Distributors. Retailers were represented by a systematic sample (every tenth entry) from the Yellow Pages under the headings Supermarkets, Retail Cosmetics and Bottle Stores. In both samplings, the directories from four major metropolitan areas - Johannesburg, Durban, Cape Town and Port Elizabeth - were used.

A total of 88 responses were obtained, representing a response retum rate of $27 \%$. The percentage response rate was, however, different for different positions in the value chain, as summarized in Table 2.

Cross tabulations and Correspondence Analysis were used to analyze the categorical data. The Correspondence Analysis output provides a measure of the degree of association between the packaging attributes and a descriptive interpretation of the sub-group characteristics. In this way, position
Table 2 Respondent summary

\begin{tabular}{lccc}
\hline $\begin{array}{l}\text { Position in value } \\
\text { chain }\end{array}$ & $\begin{array}{c}\text { Sample } \\
\text { frame }\end{array}$ & $\begin{array}{c}\text { Number of } \\
\text { responses }\end{array}$ & $\begin{array}{c}\text { Response } \\
\text { rate }\end{array}$ \\
\hline Raw material suppliers & 10 & 6 & 60 \\
Packaging suppliers & 150 & 41 & 27 \\
FMCG suppliers & 118 & 34 & 29 \\
Retailers & 53 & 7 & 13 \\
Total & 331 & 88 & 27 \\
\hline
\end{tabular}

in the value chain was correlated with the relative importance of packaging attributes.

The raw data obtained from the packaging and environmental issues parts of the questionnaire was rescaled using Correspondence Analysis in order to convert ordinal data to interval data, and thus allow mathematical manipulation of the data. There was no significant difference between the interval and the ordinal data, except for the rescaling of 4.000 to 4.456 . This indicates that the respondents view 'not yet involved' and 'irrelevant' as similar in meaning.

Answers to the open-ended question, 'Why is there current interest in environmental packaging issues?', was handled qualitatively using 'The Survey System' verbatim report.

The reliability of the response data on packaging attributes was tested by comparing the co-ordinates of two similar statements on the Correspondence plot. The statements 'reusability of package' and 'package can be reused' were utilized for this purpose. The response to these questions was found to be similar, indicating reliability of response.

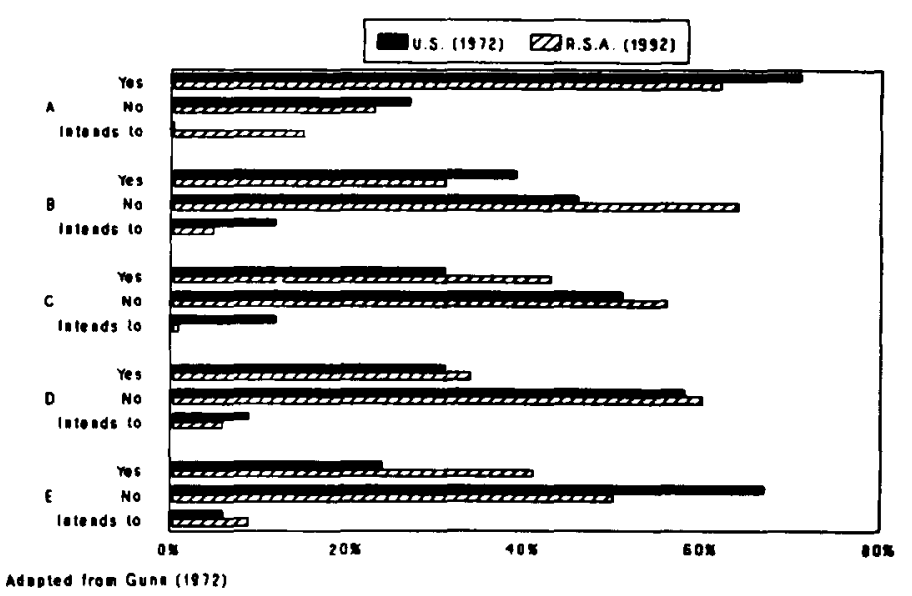

Is your company concerned about the disposability of the packages it uses or produces?

Has your company spent money for research on package disposability?

Has your company made a change in packaging to improve disposability?

llave you or your company stressed the recyclability of your package as a marketing benefit?

Have you or your company stressed your use of recycled material in your packages as a marketing benefit ?

Figure 2 Comparison of U.S. and R.S.A. respondents to Gunn (1972) questionnaire 


\section{Discussion of results}

The response in terms of the size of the companies was weighted slighly toward larger companies (35\% of respondents had 500 or more employees), although smaller organizations are represented (17\% had less than 50 employees).

The industries in which the respondents operated were food - 32\%, pharmaceutical - $19 \%$, cosmetic - 16\%, beverage $-17 \%$, and other $-16 \%$.

Involvement in the packaging decision was dominated by internal sales and/or marketing departments, although other departments and the CEO were involved in a number of instances.

Materials used or produced by the respondents in their packaging was spread across all the possible packaging materials identified in the solid waste stream of modem economies.

Correspondence Analysis on the ratings of the 36 packaging attributes indicates that $91 \%$ of the variance in the data is provided by a two-factor solution. The Correspondence plot is shown in Figure 2.

The degrees of importance are designated as follows: $I$ = unimportant, II = mildly important, III = important, IV = very important, $\mathrm{V}=$ extremcly important. Numbers 1 to 36 represent the numbers of the statements in the packaging questionnaire.

Thus attributes that are considered to be extremely important to the value chain are: consumer acceptance (statement 30), protection of product (1), and repeat purchase by consumer (15). Those attributes regarded as unimportant are returnable (9), reusable (26), recoverable (16), and microwave suitability (19). Most of the packaging attributes fall near the neutral point.

The importance of the functional and marketing aspects of packaging, as described by Marcus (1975), Marx \& Van der Walt (1989) and Danton de Rouffignac (1990), have been confirmed by these results. The functional aspects, namely: protection of product (1), long-shelf life of product (12), ease of stacking (23) and handling (10), are perceived as being mildly to extremely important by the value chain. The marketing aspects, namely: consumer convenience (4), consumer acceptance (30), repeat purchase by consumers (15), enhancing corporate (11) and brand identity (32), label specifying contents clearly (25), ease of opening (28), and promotion for the marketer (33) are also considered to be mildly to extremely important, though having slightly lower weighting than the functional aspects.

The constraints identificd by Marcus (1975) are reinforced by the value chain in this study. However, they vary in their degree of importance. Cost and consistency with corporate image are confirmed since low cost packaging (3), enhances corporate identity (11) and brand character (32) are viewed as being mildly to extremely important. Conformance to national and provincial laws is covered by the acknowledged relevance of labelling legal requirements (13) and bar-coding considerations (22). Minimizing environmental pollution is not considered a relevant constraint by the value chain as recyclability (6), returnability (9), recoverability (16), disposability (29) and reusability (26) were rated unimportant.
Thus, the study supports the literature by stressing the functional and marketing aspects of packaging, with a varying response to the constraints, and little importance attributed to environmental issues.

Cross tabulation of the mean rescaled scores of each position in the value chain with the packaging attributes was subjected to the doubling technique described by Bendixen (1991). The Correspondence Analysis output applied to the doubled matrix indicates the following differences across the value chain:

- Raw material suppliers are concemed about the reusability of the material they supply.

- FMCG suppliers are interested in shelf space at retailers, rescalability of package, enhancing the brand character, marketing promotions, see-through packages and pilferage/tamper evident packages.

- Ease of price marking and see-through packages are important for retailers. This is far fewer variables than identified by Danton de Rouffignac (1990).

- Packaging converters are concerned with resealability of packages and bar-coding considerations. Their preference for single material packages is probably due to easier processing and manufacturing. New packaging forms and devices are important if converters are seen to be proactively satisfying their customer's needs.

The consumcr's needs outlined by Packaging and Packaging Week were ease of opening, microwave suitability, minimal packaging and recyclable packaging. The value chain has acknowledged some of these needs by rating maximum convenience for consumers (4), ease of opening (28) and material reduction used in package (14) highly. However microwave suitability (19) and recyclability (6) are regarded as unimportant.

There appears to be an anomaly between the demands of consumers and retailers, as described in the literature, and the indifference of the value chain in recognizing them during the packaging decision. Furthermore, even though 'a change in consumer's values' was nominated as the main reason for the current interest in environmental packaging issues, consumer or customer surveys did not feature as important external communication sources for the respondents. Speculation as to the reason for the anomaly is that the literature sources of consumer needs originate from U.S. and U.K. consumer surveys.

Generally, South Africa's less sophisticated consumers do not have requirements for microwave packaging or have an environmental packaging awareness. This confirms the opinions of Wilken (1992) of the South African Co-ordinating Consumer Council who refers to the consumer's poor understanding of packaging environmental issues, poor education and their concentration on life's basic priorities.

The results of the respondent's perceptions of the involvement of their company's in environmental packaging issues is shown in Table 3.

The data is probably skewed towards greater involvement than actually exists due to respondent desire to be seen as being active in this area.

Altogether $86 \%$ of respondents gave the reason for the current interest in environmental issues with regard to packaging as being a change in consumers values. Altogether 7\% indicated that it is a mere $\mathrm{fad}$, and $8 \%$ answered that they 
Table 3 Perceptions of involvement

\begin{tabular}{lc}
\hline $\begin{array}{l}\text { Organizational involvement } \\
\text { sub-groups }\end{array}$ & Percentage \\
\hline Leadership position & $13 \%$ \\
Actively involved & $36 \%$ \\
Starting to take action & $28 \%$ \\
Not yet involved & $19 \%$ \\
No intention of being involved & $4 \%$ \\
\hline
\end{tabular}

didn't know the reason. The response to 'other' produced responses which can be split into those which reflect the concept as a social issue, and those where the influence is from the media or overseas. Social issues were (reported verbatim):

- Awareness of effects of environmental damage

- Concern for the environment

- Global environmental awareness

-Guilt

- Social responsibility

- For a cleaner world

- Look around you, there is a real world

- The 'green' movement worldwide

- Fundamental issuc in today's world

Media and overseas pressure were reflected by (reported verbatim):

- A view brought to Africa from the West

- Enhanced media focus on environmental issues

- Media coverage, i.e. the program ' $50 / 50$ '

- Half truths spread by media and do-gooders

- Mcdia hype, European priorities and US experience

- Overseas awareness spilling into SA

- Export requirements and legal changes

- Image of multinationals

-Following overseas examples
Recorded in Table 4 is the interest which the packaging value chain shows regarding the suggestions from Freeman (1980) and Selke (1990) on how to reduce the impact of packaging in the waste stream.

Correspondence Analysis indicates that the majority of the suggestions are considered irrelevant by the value chain. However, there are activities which the value chain are attending to.

Reduction in the weight of package (9) is the most important activity, which probably occurs for economic reasons rather than for environmental motives. The expressed activity to eliminate heavy metals from the package (1), e.g. lead-based pigments, is believed to be mainly due to the increasing awareness of packaging of FMCG suppliers and trends away from their use in packaging worldwide.

Those activities which are not yet part of packaging design for the sample as a whole include retumability (2), reusability (4) and providing containers and infrastructure for consumer recycling (10). However, there are visible examples of company sponsored recycling schemes which reflect the strategies of more innovative companies, e.g. Consol Glass and SAB glass recycling bins.

In Figure 3, the responses to the Gunn (1972) questionnaire between U.S. readers of Packaging Engineering in 1972 with South African replies to this current study, are compared.

The majority (62\%) of South African respondents are concerned about the disposability of the packages they use or produce. However, only a third have spent money on rescarch into disposability. Altogether $43 \%$ claim to have made a change to the package to improve disposability. Between 34 and $41 \%$ of respondents have stressed the recyclability or the use of recycled materials as a marketing benefit. Generally, the responses are characterized by a third being actively involved in addressing environmental packaging issues. The majority are not concerned and there appears to be liule intention to be more pro-active.

Table 4 Response to Selke \& Freiman suggestions (Frequency table)

\begin{tabular}{|c|c|c|c|c|c|}
\hline Environmental packaging issues & Leader & Active & Starting & Not yet & Irrelevant \\
\hline \multicolumn{6}{|l|}{ Eliminate heavy metals from package, } \\
\hline e.g. lead-based pigments & 17 & 20 & 9 & 10 & 32 \\
\hline Designed to be retumable & 7 & 7 & 9 & 18 & 47 \\
\hline Designed for waste reduction in landfill & 11 & 10 & 13 & 23 & 31 \\
\hline Designed to be reusable & 8 & 10 & 5 & 24 & 41 \\
\hline Designed for recyclability & 12 & 19 & 16 & 19 & 22 \\
\hline Use single material type where possible & 11 & 23 & 12 & 14 & 28 \\
\hline \multicolumn{6}{|l|}{ Use materials which are easily } \\
\hline separated or compatible & 10 & 23 & 12 & 18 & 25 \\
\hline Use recycled materials & 14 & 17 & 14 & 16 & 27 \\
\hline Reduction in weight of package & 16 & 33 & 4 & 13 & 22 \\
\hline \multicolumn{6}{|l|}{ Provide containers + infrastructure for } \\
\hline consumer recycling & 6 & 10 & 5 & 32 & 35 \\
\hline \multicolumn{6}{|l|}{ Reduction in energy required to } \\
\hline manufacture/recycle packaging & 4 & 13 & 9 & 23 & 39 \\
\hline Designed to be biodegradable & 6 & 9 & 15 & 19 & 39 \\
\hline
\end{tabular}




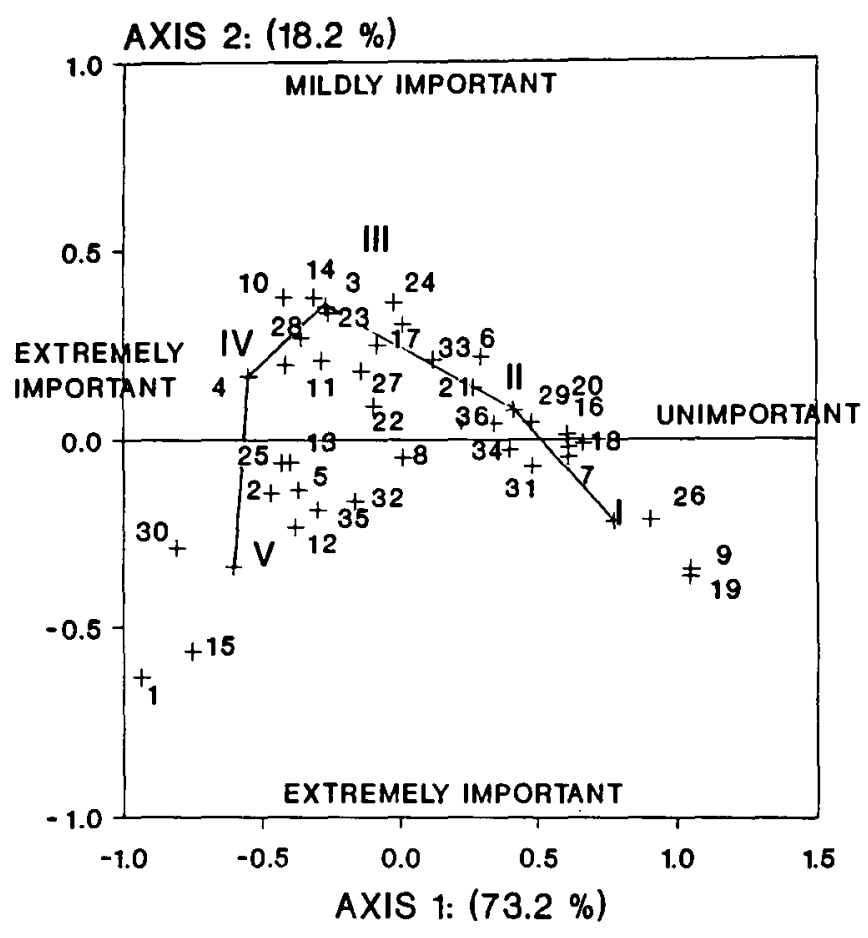

Figure 3 Correspondence plot of packaging attributes

Visual comparison illustrates the differences between the South African and American responses. Concern for disposability of packages is shown by the majority of respondents. South African companies are less active as far as concem for disposability and research expenditure is concerned. South African organizations are more active than their American counterparts (in the 1972 survey) in trying to improve disposability, stressing recyclability and using recycled materials as a marketing benefit.

In comparison with the current European and American attitudes and practice with regard to environmental packaging issues, South African companies appear to be well behind. However, there are signs that packaging converters, FMCG and raw material suppliers are responding to the issues identified from overseas and media sources.

\section{Conclusion}

This research has indicated that the functional aspects of packaging have more significance than the marketing aspects as far as the members of the South African packaging value chain are concerned. Environmental concerns are rated as unimportant. This is despite evidence that this issue should be regarded with increasing importance based on international trends.

However, the relative importance of environmental packaging issues is greatest amongst raw material suppliers, followed by packaging and FMCG suppliers. Retailers have the least interest.

Compared with American respondents in 1972, the current South African packaging value chain exhibits a similar pattern of responses to the Gunn (1972) questionnaire on how they view the environmental packaging challenge.

The packaging value chain's prime motivation for involvement in environmental issues appears to be generated from external rather than internal sources. External communication sources feature as the dominant information channels throughout the value chain. In addition, a change in consumer's values was acknowledged as the main pressure for change by the majority of respondents, representing a 'pull' strategy within the value chain.

It is apparent that little change in attitude or practice will occur if the decision on environmental aspects of packaging is left to the packaging value chain. Any changes will have to be generated externally, either through consumer demand, or legislation. Legislation in this area is unlikely to be of prime importance in the current South African environment. Reliance will therefore have to be placed on consumer and legislative pressure from sources external to South Africa. This is likely to affect only the larger companies that are exporting to overseas markets such as the U.S. and E.U..

Exporters to these areas will be forced to comply with environmental packaging requirements, either due to consumer trends or legislation. If the packaging does not meet consumers environmental requirements as well as other competitors, the markcting concept indicates that the consumer will cease purchasing from that supplier, resulting in decreased demand and profitability. The power of legislation is evidenced by the current change in the paper manufacturing process in South Africa from chemical bleaching to oxygen bleaching, in order to meet projected legislative requirements in the E.U..

Thus the driving force in the consideration of environmental aspects of packaging in South Africa is likely to be external to South Africa, and to occur through companies involved in export.

\section{References}

Ashton. 1991. Packaging. June, pp.32-36.

Bendixen, M.T. 1991. Correspondence analysis. Unpublished Working Paper. Johannesburg: University of the Witwatersrand.

Caimcross, F. 1990. 'The environment: an enemy and yet a friend', The Economist, September 8.

Danton de Rouffignac, P. 1990. Packaging in the marketing mix. London: Butterworth-Heineman Ltd.

Davidson, A. 1986. Aspects of the packaging decision. Unpublished research report submitted in partial fulfilment of the MBA degree. Johannesburg: University of Witwatersrand.

Dick, G.C. 1978. The non-returnable beverage container problem in South Atrica: analysis and recommendations. Unpublished research report submitted in partial fulfilment of the MBA degree. Cape Town: University of Cape Town.

Erikson. 1992. Packaging. April, pp.43.

Freeman, L. 1989. 'Consumers thinking "Green" too', Advertising Age, 21 August, pp.66.

Freeman, DJ. 1980. Key social issues for packaging in the 1980s. New York: Amacom.

Gunn, W.N. 1972. 'Packagers and the environmental challenge', Harvard Business Review, July-August.

Hunt. 1992. Packaging Week, February, pp.13.

Kotler, P. 1991. Marketing management - analysis, planning and control. Seventh Edition, Englewood Cliffs, New Jersey: Prentice-Hall Inc.

Marcus, B.H. 1975. Modern marketing. New York, Random House. 
Marx, S. \& Van der Walt, A. 1989. Marketing management. Cape Town: Juta, p.230.

McDaniel, S.W. \& Rylander, D.H. 1993. 'Strategic green marketing', Journal of Consumer Marketing, Vol. 10, No. 3: 4-10.

Perchard, D. 1992. 'Packaging and the environment', Section II. Impact of Legislation, Europe, pp.31-46. England: Published jointly by Pira International and Packaging Week.

Phelps, D.M. \& Westing, J.H. 1968. Marketing management. Third Edition, Homewood, Illinois: Irwin.

President's Council Report on a National Environmental Management System. 1991. Cape Town: The Government Printer.

Puplick, C. 1992. 'Packaging and the environment', Section II. Impact of Legislation, The Pacific Rim, pp. 11 - 29. England: Published jointly by Pira International and Packaging Week.

Rice, G. 1990. 'Being green: US marketers begin to respond'. Academy of Marketing Science News, April, pp.5.
Runyon, K.E. 1982. The practice of marketing. Columbus, Ohio: Merrill.

Selke, S.E.M. 1990. Packaging and the environment. Alternatives, trends and solutions. Lancaster: Technomic Publishing Co., Inc.

Stanton, WJ., Etzel, M.J., Walker, B.J., Abratt, R., Pitt, L. \& Staude, G.E. 1989. Marketing management in Sowh Africa. Johannesburg: Butterworths.

The Buyer's Guide 1992/3 - The directory for manufacturers of food, beverages, pharmaceuticals, cosmetics, toiletries and packaging. Cape Town: National Publishing (Pty) Lid.

Wilken. I. 1992. Litter abatement with an emphasis on measures to reduce the amount of packaging as a component in the total volume of the waste stream. Market forces and trends with subdivisions, perceptions, values and the Third World. Pretoria: 3 July 1992. S.A. Consumer Co-ordinating Council Workshop. 